\title{
Inhibitory effect and mechanism of gelatin stabilized ferrous sulfide nanoparticles on porcine reproductive and respiratory syndrome virus
}

\author{
Ting Tong ${ }^{1}$, Shuangfei Deng ${ }^{1}$, Xiaotong Zhang ${ }^{1}$, Liurong Fang ${ }^{2}$, Jiangong Liang ${ }^{1^{*}}$ (D) and Shaobo Xiao ${ }^{2^{*}}$
}

\begin{abstract}
Background: The infection and spread of porcine reproductive and respiratory syndrome virus (PRRSV) pose a serious threat to the global pig industry, and inhibiting the viral infection process is a promising treatment strategy. Nanomaterials can interact with viruses and have attracted much attention due to their large specific surface area and unique physicochemical properties. Ferrous sulfide nanoparticles (FeS NPs) with the characteristics of high reactivity, large specific surface area, and low cost are widely applied to environmental remediation, catalysis, energy storage and medicine. However, there is no report on the application of FeS NPs in the antiviral field. In this study, gelatin stabilized FeS nanoparticles (Gel-FeS NPs) were large-scale synthesized rapidly by the one-pot method of co-precipitation of $\mathrm{Fe}^{2+}$ and $\mathrm{S}^{2-}$.

Results: The prepared Gel-FeS NPs exhibited good stability and dispersibility with an average diameter of $47.3 \mathrm{~nm}$. Additionally, they were characterized with good biocompatibility and high antiviral activity against PRRSV proliferation in the stages of adsorption, invasion, and replication.

Conclusions: We reported for the first time the virucidal and antiviral activity of Gel-FeS NPs. The synthesized Gel-FeS NPs exhibited good dispersibility and biocompatibility as well as effective inhibition on PRRSV proliferation. Moreover, the $\mathrm{Fe}^{2+}$ released from degraded Gel-FeS NPs still displayed an antiviral effect, demonstrating the advantage of Gel-FeS NPs as an antiviral nanomaterial compared to other nanomaterials. This work highlighted the antiviral effect of Gel-FeS NPs and provided a new strategy for ferrous-based nanoparticles against PRRSV.
\end{abstract}

Keywords: Ferrous sulfide nanoparticles, Antiviral mechanism, Porcine reproductive and respiratory syndrome virus, Inactivation, Adsorption, Invasion, Replication, Release

\footnotetext{
*Correspondence: liangjg@mail.hzau.edu.cn; vet@mail.hzau.edu.cn

${ }^{1}$ College of Resource and Environment, College of Science, State Key

Laboratory of Agricultural Microbiology, Huazhong Agricultural University,

No.1 Shizishan Street, Hongshan District, Wuhan 430070, Hubei, People's

Republic of China

2 State Key Laboratory of Agricultural Microbiology, College of Veterinary

Medicine, Key Laboratory of Preventive Veterinary Medicine in Hubei

Province, The Cooperative Innovation Center for Sustainable Pig

Production, Huazhong Agricultural University, No.1 Shizishan Street,

Hongshan District, Wuhan 430070, Hubei, People's Republic of China
}

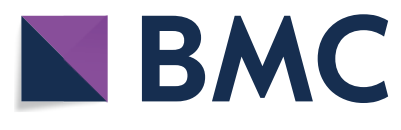

(C) The Author(s) 2022. Open Access This article is licensed under a Creative Commons Attribution 4.0 International License, which permits use, sharing, adaptation, distribution and reproduction in any medium or format, as long as you give appropriate credit to the original author(s) and the source, provide a link to the Creative Commons licence, and indicate if changes were made. The images or other third party material in this article are included in the article's Creative Commons licence, unless indicated otherwise in a credit line to the material. If material is not included in the article's Creative Commons licence and your intended use is not permitted by statutory regulation or exceeds the permitted use, you will need to obtain permission directly from the copyright holder. To view a copy of this licence, visit http://creativecommons.org/licenses/by/4.0/. The Creative Commons Public Domain Dedication waiver (http://creativeco mmons.org/publicdomain/zero/1.0/) applies to the data made available in this article, unless otherwise stated in a credit line to the data. 


\section{Graphical Abstract}

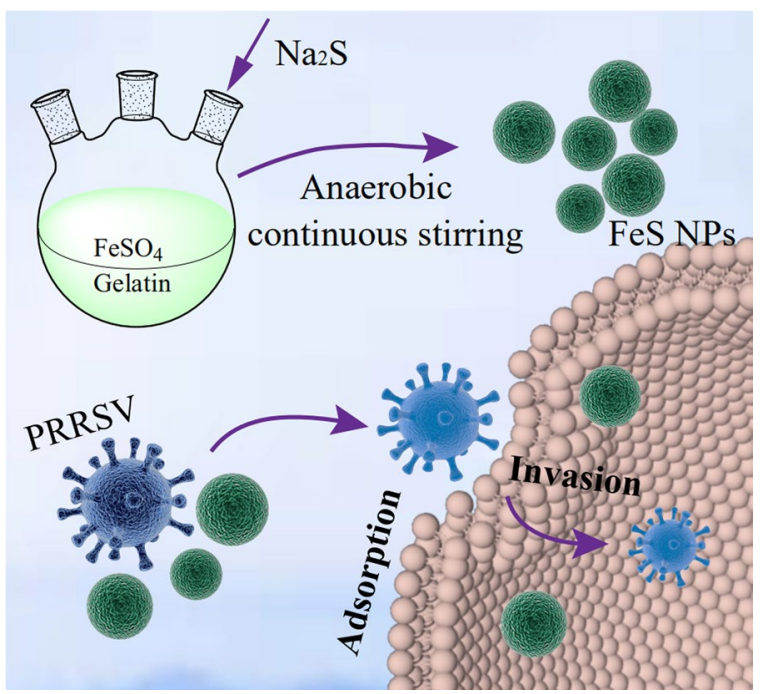

\section{Introduction}

Porcine reproductive and respiratory syndrome (PRRS) is a disease that causes reproductive failure in breeding sows and respiratory disorders in growing pigs [1]. The etiologic agent, PRRS virus (PRRSV), an enveloped, single positive-stranded RNA virus of the family Arteriviridae [2], has caused huge economic losses in the swine industry worldwide in the past three decades, due to its persistent mutation and epidemic caused by the high variability of the RNA virus genome, making its prevention and treatment still unsatisfactory [3]. This suggests the necessity to develop novel antiviral strategies against PRRSV by inactivating the virus from the initial stage of infection.

In recent years, a series of innovative nanomaterials with potential activities against various viruses have been reported to play an important role in preventing and treating different viral infections [4-8], such as DNA origami [9], graphene nanosheets [10, 11], fullerene nanospheres [12-14], macromolecular polymers [15], nano hydrogels [16-18], and other emerging materials $[19,20]$. These nanomaterials can play an antiviral role in the different stages of the virus life cycle, but their further application was restricted by the low synthesis yield and the complex synthesis procedures, suggesting the rare advantage of the one-pot method for rapid and large-scale synthesis of antiviral nanomaterials with good reproducibility.

Meanwhile, iron-based antiviral materials have also attracted much attention. Iron ions are essential trace elements for cell growth and prevention of cancer, cardiovascular disease, and diabetes [21, 22]. The iron-based complexes were reported to have a specific antiviral effect on various viruses [23, 24], and the use of iron ions as a supplementary therapy proved to be a promising antiviral strategy $[25,26]$. However, the strong oxidizability of iron ions may have a certain degree of harm to cells, despite the extensive application of iron supplement with ferrous ions in the prevention and treatment of iron deficiency anemia [27, 28]. Owing to its specific physical and chemical properties, ferrous sulfide nanoparticles (FeS NPs) has been studied in many fields, such as anti-tumor, energy, sewage treatment, and so on $[29,30]$, but to our knowledge, no study has ever been performed on its antiviral effects. Due to the instability and easy oxidation of FeS in aqueous solution, we improved the stability of FeS NPs by introducing gelatin into the reaction system [31]. As a biomedical material, gelatin has various attractive features, such as biocompatibility, low immunogenicity, biodegradability, and easy manipulation [32, 33].

In this study, we reported the inhibitory effect and mechanism of gelatin stabilized ferrous sulfide nanoparticles (Gel-FeS NPs) on PRRSV. The antiviral agent was synthesized by the co-precipitation method, and GelFeS NPs were shown to possess strong inhibitory effects against PRRSV proliferation, not only inactivating the PRRS virions, but also suppressing PRRSV adsorption, invasion, and replication in the host cell. To the best of our knowledge, this is the first report about the virucidal and antiviral activity of ferrous-based nanoparticles. This work highlighted the antiviral effect of Gel-FeS NPs and provided a new strategy for ferrous-based nanoparticles against PRRSV. 


\section{Results}

\section{Characterization of Gel-FeS NPs}

Gelatin stabilized FeS NPs were simply synthesized by the co-precipitation method [34]. The precursors containing the ferrous ions of $\mathrm{FeSO}_{4}$ and $\mathrm{S}^{2-}$ of $\mathrm{Na}_{2} \mathrm{~S}$ were co-precipitated in the nitrogen-protected aqueous solution under continuous stirring. The morphology and size distribution of Gel-FeS NPs were measured using a transmission electron microscope (TEM) and dynamic light scattering (DLS) analyzer. In the TEM image (Fig. 1A), Gel-FeS NPs were seen to be well-dispersed in aqueous solution with a uniform size, and 100 nanoparticles were selected to calculate the diameter of Gel-FeS NPs, which showed an average diameter of $47.3 \mathrm{~nm}$. Moreover, the lattice structure in the interior of Gel-FeS NPs can be observed in the high-resolution TEM images (Fig. 1B), and Gel-FeS NPs presented a clear lattice diffraction pattern with a lattice spacing of $0.244 \mathrm{~nm}$. The average diameter of hydrated particles of Gel-FeS NPs was measured to be $70.9 \mathrm{~nm}$ by dynamic light scattering (DLS) instrument (Fig. 1C). Figure 1D shows the UV-Vis spectra of $\mathrm{FeSO}_{4}, \mathrm{Na}_{2} \mathrm{~S}$, gelatin, and Gel-FeS NPs, with negligible absorption for the individual solutions of $\mathrm{FeSO}_{4}, \mathrm{Na}_{2} \mathrm{~S}$ and gelatin in the longer wavelength region over $250 \mathrm{~nm}$. After mixing these three reagents and reaction, the black product could be observed, which showed strong absorbance in the wavelength range of $200-500 \mathrm{~nm}$, further confirming the successful formation of Gel-FeS NPs. After storage at $4{ }^{\circ} \mathrm{C}$ for a week, Gel-FeS NPs showed no notable change in the UV-Vis spectra (Additional file 1: Fig. S1), implying their good physical and chemical stability in different aqueous solutions (Additional file 1: Fig. S2).

The molecular structure and chemical bond information were obtained by Fourier transmission infrared spectroscopy (FTIR) analysis of Gel-FeS NPs and gelatin to study the differences in functional groups (Fig. 1E). The peaks at $3434 \mathrm{~cm}^{-1}$ were assigned to the $\mathrm{O}-\mathrm{H}$ stretching vibrations from adsorbed water and the stabilizer gelation. The abundant $\mathrm{O}-\mathrm{H}$ bonds in gelatin were attributed to the formation of strong intermolecular hydrogen bonds between gelatin and FeS NPs, which improved the stability of Gel-FeS NPs effectively. Moreover, the absorption peaks at around $1645 \mathrm{~cm}^{-1}$ and

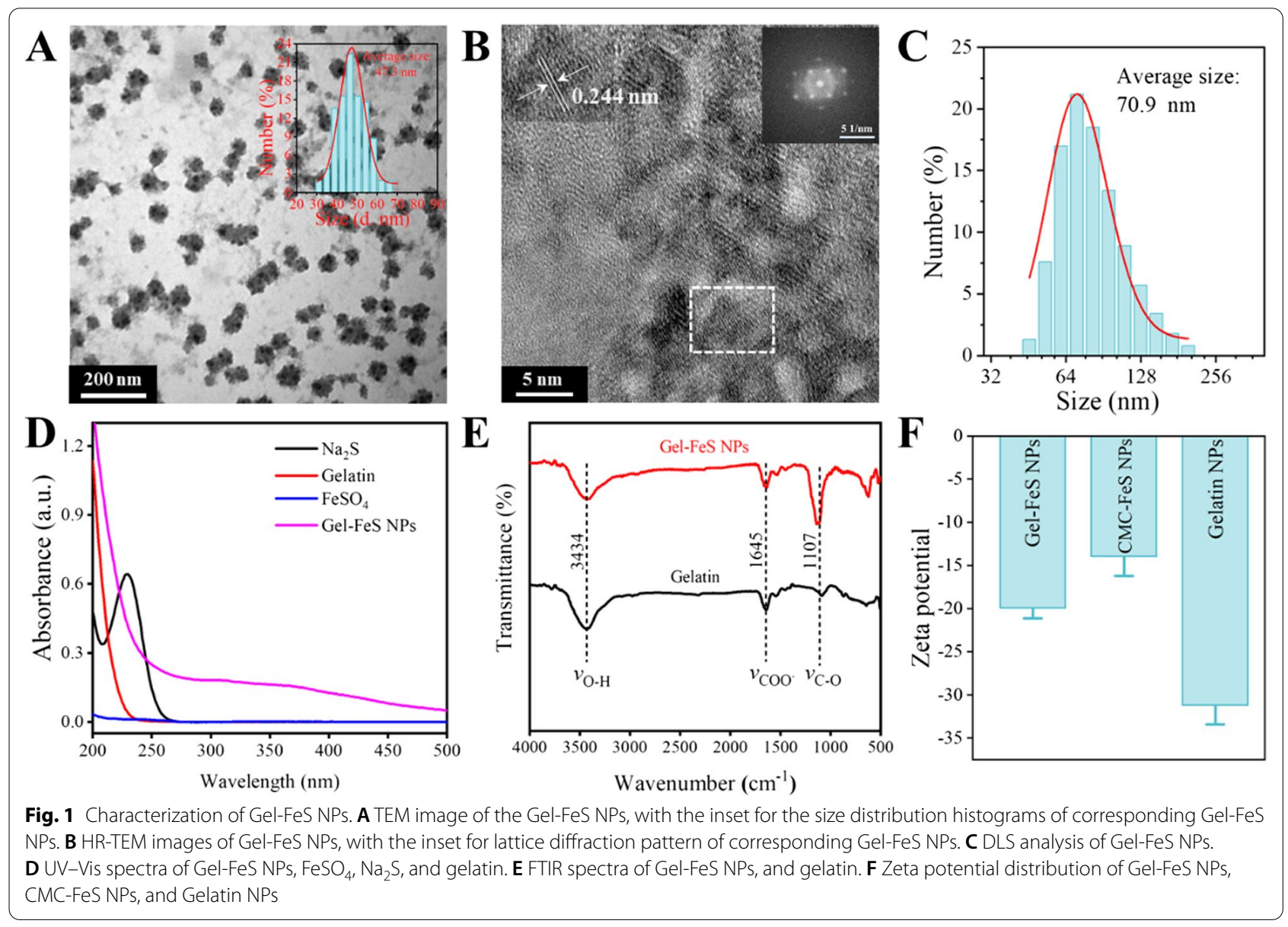


$1107 \mathrm{~cm}^{-1}$ indicated the stretching vibrations of $-\mathrm{COO}^{-}$ and $\mathrm{C}-\mathrm{O}-\mathrm{C}$, respectively. The modification of gelatin provided electrostatic repulsion and steric hindrance for FeS to avoid oxidation and aggregation [35]. In order to compare the properties of Gel-FeS NPs, carboxymethyl cellulose (CMC) modified FeS nanoparticles (CMC-FeS NPs) were synthesized using the one-pot method of coprecipitation of $\mathrm{Fe}^{2+}$ and $\mathrm{S}^{2-}$, gelatin nanoparticles (Gelatin NPs) were synthesized by the crosslinking method, the former of which is elliptical, while the latter is circular (Additional file 1: Fig. S3). Dynamic light scattering results showed that their hydrated particle sizes are $95.0 \mathrm{~nm}$ and $148.4 \mathrm{~nm}$, respectively (Additional file 1: Fig. S4). Zeta potentials of the three nanoparticles were recorded in Fig. 1F.

Meanwhile, the XRD diffraction pattern of Gel-FeS NPs was analyzed (Fig. 2A). The two typical peaks at $2 \theta=23.0^{\circ}$ and $47.0^{\circ}$ represented $\mathrm{FeS}$, and the diffraction peak at $2 \theta=49.8^{\circ}$ corresponded to $\left(\begin{array}{lll}2 & 0 & 0\end{array}\right)$ reflection of FeS, indicating the crystal form of FeS in the presence of gelatin [36]. Additionally, the peak at $2 \theta=36.4^{\circ}$ corresponded to iron oxides, probably due to partial oxidation of Gel-FeS NPs during sample drying and analysis. In Fig. 2B, the components and surface functional groups of Gel-FeS NPs were characterized by X-ray photoelectron spectroscopy (XPS) analysis, and the XPS full scan spectrum exhibited five obvious peaks at the binding energy of 163.30, 399.14, 530.98, 582.20 and $710.57 \mathrm{eV}$, corresponding to $\mathrm{S} 2 \mathrm{p}, \mathrm{C} 1 \mathrm{~s}, \mathrm{~N}$ $1 \mathrm{~s}, \mathrm{O} 1 \mathrm{~s}$, and Fe 2p orbital, respectively. The high resolution XPS spectra of $\mathrm{C} 1 \mathrm{~s}$ could be resolved into four peaks at 284.81, 286.12, 287.87, and $288.52 \mathrm{eV}$, indicating the presence of $\mathrm{C}-\mathrm{C}, \mathrm{C}-\mathrm{O}-\mathrm{C}, \mathrm{C}=\mathrm{O}$, and $\mathrm{O}-\mathrm{C}=\mathrm{O}$ bonds in Gel-FeS NPs, respectively (Fig. 2C). In the high resolution XPS spectra of Fe 2p (Fig. 2D), the peak at $710.92 \mathrm{eV}$ was assigned to $\mathrm{Fe}(\mathrm{II})-\mathrm{S}$ species, the main form of element Fe in Gel-FeS NPs, and the peaks at 719.04 and $724.33 \mathrm{eV}$ were attributed to $\mathrm{Fe}(\mathrm{II})-\mathrm{O}$ and $\mathrm{Fe}(\mathrm{III})-\mathrm{O}$, respectively, implying the partial oxidization of Gel-FeS NPs during storage and detection as previously reported [37]. In the high resolution XPS spectra of $\mathrm{S} 2 \mathrm{p}$ (Fig. 2E), the peak at $161.50 \mathrm{eV}$ was ascribed to $\mathrm{FeS}$, corresponding to the peaks of $\mathrm{Fe} 2 \mathrm{p}$ at $710.92 \mathrm{eV}$, and the two peaks at 167.41 and $168.30 \mathrm{eV}$ of $\mathrm{SO}_{4}{ }^{2-}$ indicated that some sulphate impurities could not be removed thoroughly.
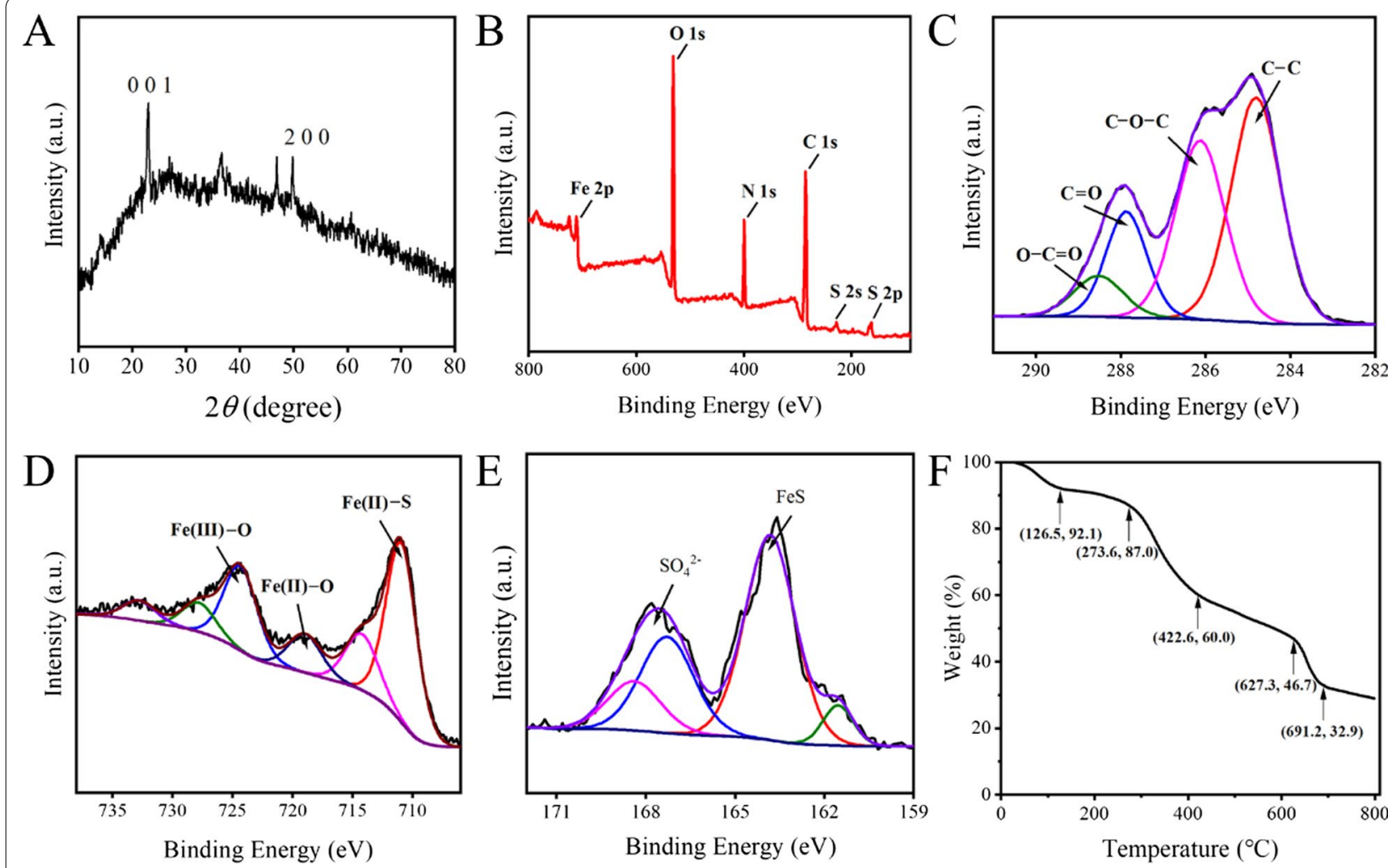

Fig. 2 A XRD pattern of Gel-FeS NPs. B X-ray photoelectron spectroscopy (XPS) full scans spectrum of Gel-FeS NPs and high-resolution XPS spectra of C C 1 s, D Fe 2p, E S 2p. F Thermogravimetric analysis (TGA) of Gel-FeS NPs with the percentage weight loss of the sample as a function of temperature 
Gelatin is a biocompatible material without obvious biological toxicity, and we did the thermogravimetric analysis (TGA) of Gel-FeS NPs to calculate the loading of gelatin (Fig. 2F). The total mass loss for Gel-FeS NPs was seen to reach $72 \%$ at $800{ }^{\circ} \mathrm{C}$, and the process of mass loss under heating can be tentatively divided into several stages: (I) $0-273.6{ }^{\circ} \mathrm{C}$, (II) $273.6-422.6{ }^{\circ} \mathrm{C}$, (III) $422.6-$ $691.2^{\circ} \mathrm{C}$, and (IV) above $691.2{ }^{\circ} \mathrm{C}$. According to previous reports [34, 38], water was the only product for Gel-FeS NPs heated up to $126.5{ }^{\circ} \mathrm{C}$, while the temperature up to $273.6{ }^{\circ} \mathrm{C}$ (stage I) corresponds to the release of water and the loss of loosely attached gelatin molecules in the absence of thermal degradation of Gel-FeS NPs. Stage II $\left(273.6-422.6{ }^{\circ} \mathrm{C}\right)$ and stage III $\left(422.6-691.2^{\circ} \mathrm{C}\right)$ are associated with gelatin degradation and thermal decomposition of gelatin on the surface of modified nanoparticles. After reaching $691.2{ }^{\circ} \mathrm{C}$, ferrous sulfide remained. Based on the TGA results, the content of FeS NPs in the whole Gel-FeS NPs is about $28 \%$, and further calculation indicated that the content of iron is $17.8 \%$.

\section{Biocompatibility of Gel-FeS NPs}

MARC-145 cells, an African green monkey kidney cell line, are highly sensitive to PRRSV, and are often used to isolate PRRSV for diagnostics, research, and vaccine production, leading to their frequent use in in vitro studies on PRRSV [39-41]. In order to study the antiviral activity of Gel-FeS NPs against PRRSV and define the experimental conditions, we first measured the biocompatibility of Gel-FeS NPs in MARC-145 cells, the host cell of PRRSV. After incubation with Gel-FeS NPs for 12, 24, 36, and $48 \mathrm{~h}$, the viability of MARC-145 cells was measured by MTT assay. In Fig. 3, Gel-FeS NPs showed negligible cytotoxicity at the concentration below $430.0 \mu \mathrm{g} / \mathrm{mL}$.

According to the TGA results, the mass fraction of $\mathrm{Fe}$ in Gel-FeS NPs is $17.8 \%$, and $430.0 \mu \mathrm{g} / \mathrm{mL}$ of Gel-FeS NPs was estimated to contain $76.5 \mu \mathrm{g} / \mathrm{mL}$ iron element. The contents of internalized Gel-FeS in MARC-145 cells were evaluated by inductively coupled plasma-mass spectrometry (ICP-MS). As shown in Fig. 3B, the intracellular Fe content was about $4 \mathrm{pg} /$ cell in the cells without any
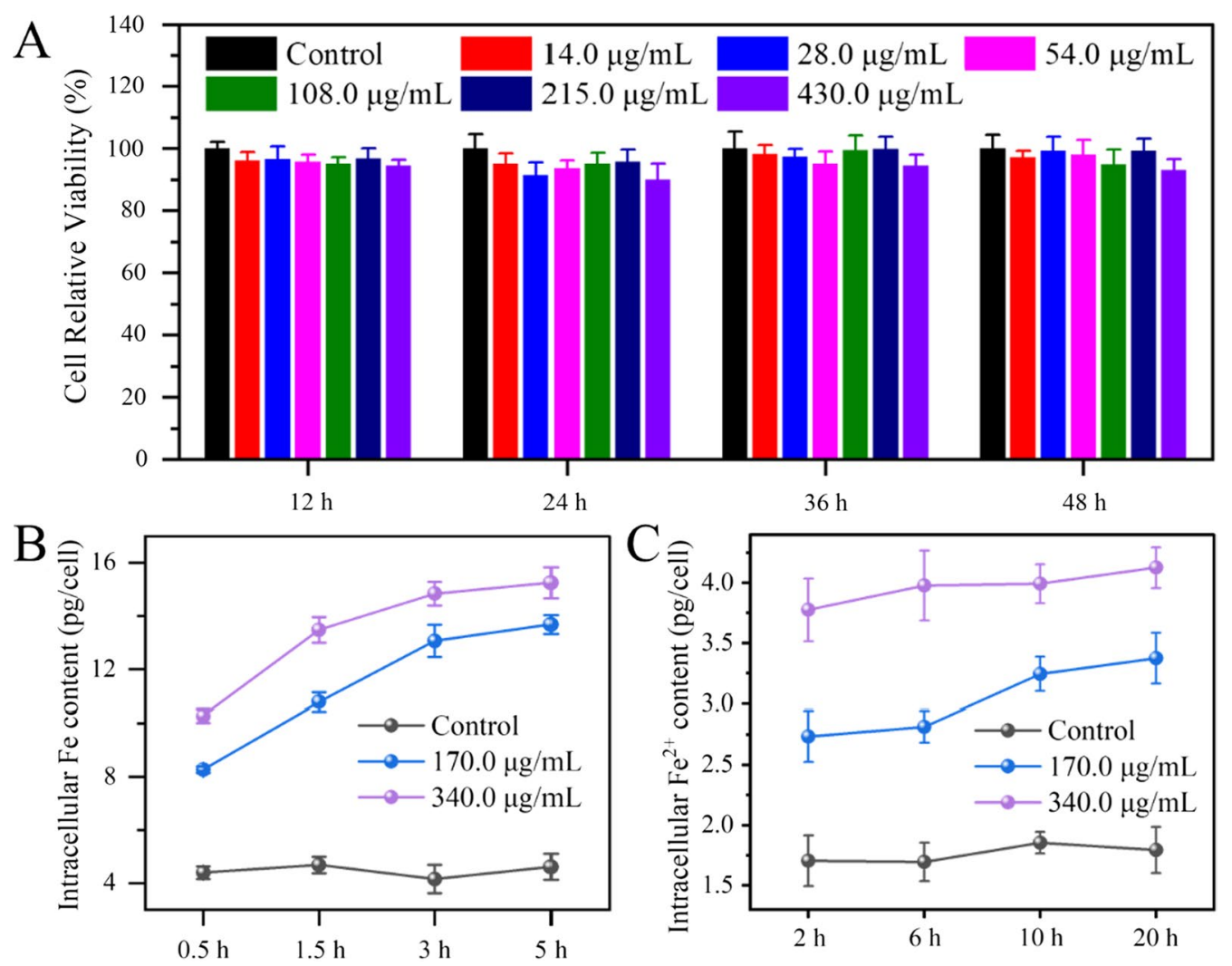

Fig. 3 A Cell cytotoxicity of different concentrations of Gel-FeS NPs $(0-430.0 \mu \mathrm{g} / \mathrm{mL})$ on MARC-145 cells. B The cellular internalization experiment of Gel-FeS NPs. After MARC-145 cells were incubated with different concentrations of Gel-FeS NPs $(0-340.0 \mu \mathrm{g} / \mathrm{mL})$, the cells were collected at the indicated time points, and the content of Fe in the cells was detected by ICP-MS. C Analysis of intracellular ferrous iron release from Gel-FeS NPS by the ferrous ion colorimetric kit after incubating MARC-145 cells with different concentrations of Gel-FeS NPs $(0-340.0 \mu \mathrm{g} / \mathrm{mL})$ and collecting the cells at the indicated time points. Control group: cells treated with the DMEM (2\% FBS). Error bars represent the standard deviation from three repeated experiments 
treatment, in contrast to $16 \mathrm{pg} / \mathrm{cell}$ in the cells incubated with $340.0 \mu \mathrm{g} / \mathrm{mL}$ Gel-FeS NPs, demonstrating that GelFeS NPs could enter the cells. Furthermore, we tested the intracellular release of $\mathrm{Fe}^{2+}$ by using the ferrous ion colorimetric kit, and the results are shown in Fig. 3C. After incubation with $340.0 \mu \mathrm{g} / \mathrm{mL}$ Gel-FeS NPs for $20 \mathrm{~h}$, the intracellular release of ferrous ions was $4.1 \mathrm{pg} / \mathrm{cell}$, which was higher than control group without any treatment (1.7 pg/cell), indicating the successful entry of GelFeS NPs into cells and the release of some ferrous ions from Gel-FeS NPs. According to the calculation, the Fe concentration used in these experiments ranged from $15.1-60.5 \mu \mathrm{g} / \mathrm{mL}$, corresponding to the concentration range of Gel-FeS NPs $(85.0-340.0 \mu \mathrm{g} / \mathrm{mL})$, which is in the similar concentration range as previously reported by Dang et al. $(0-48 \mu \mathrm{g} / \mathrm{mL}$ bio-assembled FeS nanoparticles for efficient cancer therapy) [42] and Song et al., who found $\mathrm{Fe}(\mathrm{II})$ nanoparticles did not affect the production of archaea at $0-300 \mu \mathrm{g} / \mathrm{mL}$ [43].

\section{Gel-FeS NPs exhibit inhibitory effect on PRRSV proliferation}

Based on the above cytotoxicity test results and the determined concentration range, we studied the antiviral activity of Gel-FeS NPs against PRRSV based on indirect immunofluorescence assay (IFA). In Fig. 4, compared with the control, the Gel-FeS NPs treated samples showed a significant time- and dose-dependent decline in the red fluorescence signal of Alexa Fluor ${ }^{\circledR} 594$ labeled
PRRSV N protein in the cytoplasm of MARC-145 cells, in contrast to no notable difference in the nuclei stained blue with DAPI, reflecting the good antiviral activity of Gel-FeS NPs.

Furthermore, the viral infectivity of PRRSV was determined by plaque reduction assay. In Fig. 5A, the titers of PRRSV treated by Gel-FeS NPs were seen to decrease significantly $(\mathrm{p}<0.001)$ in a dose-dependent manner relative to the control group, resulting in $\sim 10^{3}$-fold reduction in PRRSV titers. Next, we detected the RNA of PRRSV, which contains a single-stranded, positive-sense RNA genome with at least 10 open reading frames (ORFs), including ORF1a, ORF1b, ORF2a, ORF2b, ORF3, ORF4, ORF5, ORF5a, ORF6, and ORF7 [2, 44, 45]. Accordingly, the content of cellular ORF7 gene is proportional to the viral infection intensity and the number of infected cells. After incubation with Gel-FeS NPs, the cellular RNA of PRRSV infected cells was extracted and the ORF7 gene was detected by real-time quantitative reverse transcription polymerase chain reaction (RT-qPCR) to verify the inhibition of Gel-FeS NPs on virus proliferation. In Fig. 5B, the RT-qPCR results also demonstrated the excellent antiviral effect of Gel-FeS NPs on PRRSV proliferation.

\section{Gel-FeS NPs inhibit PRRSV proliferation in a multi-stage manner}

The effect of Gel-FeS NPs on the virus life cycle was investigated by analyzing their ability to directly

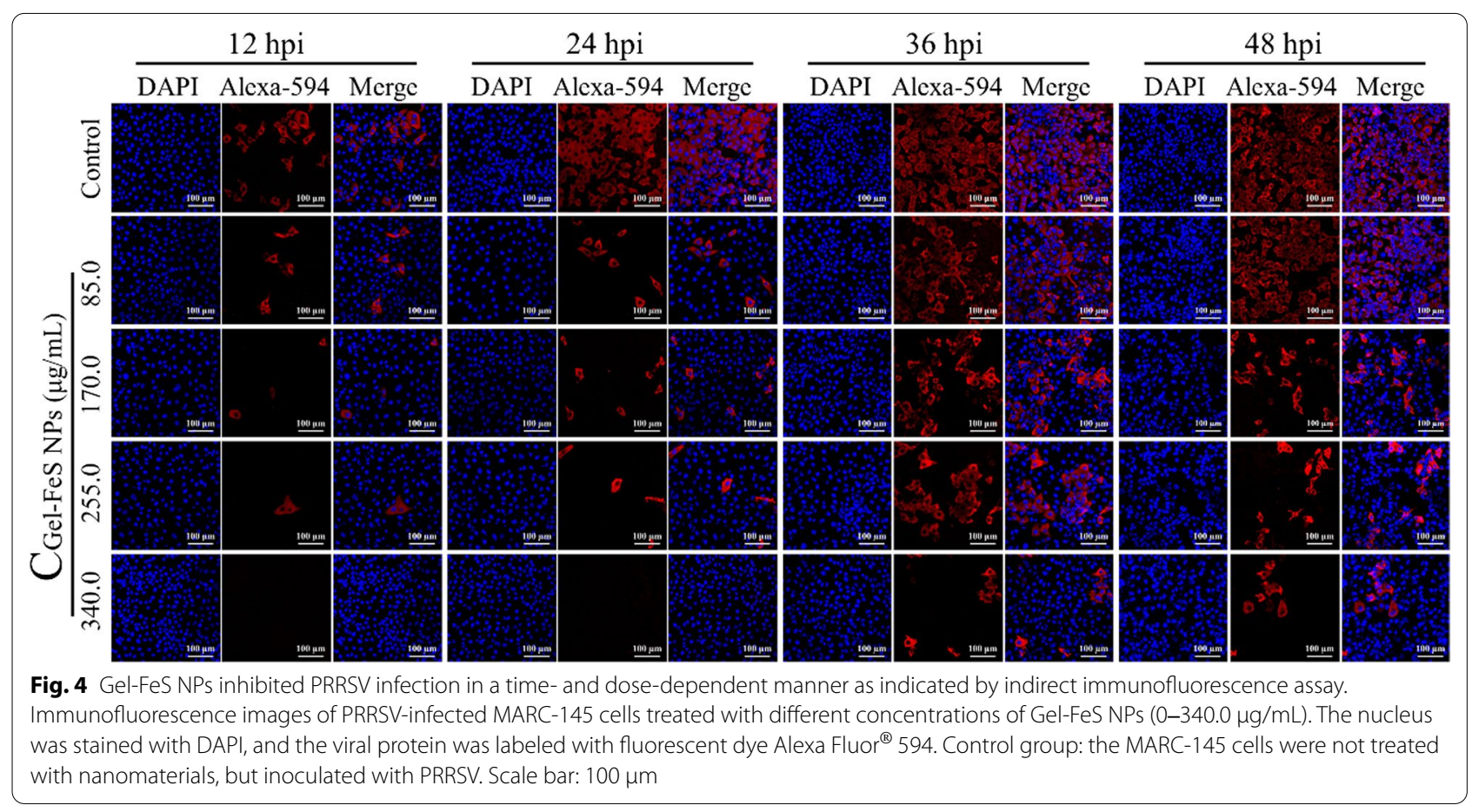




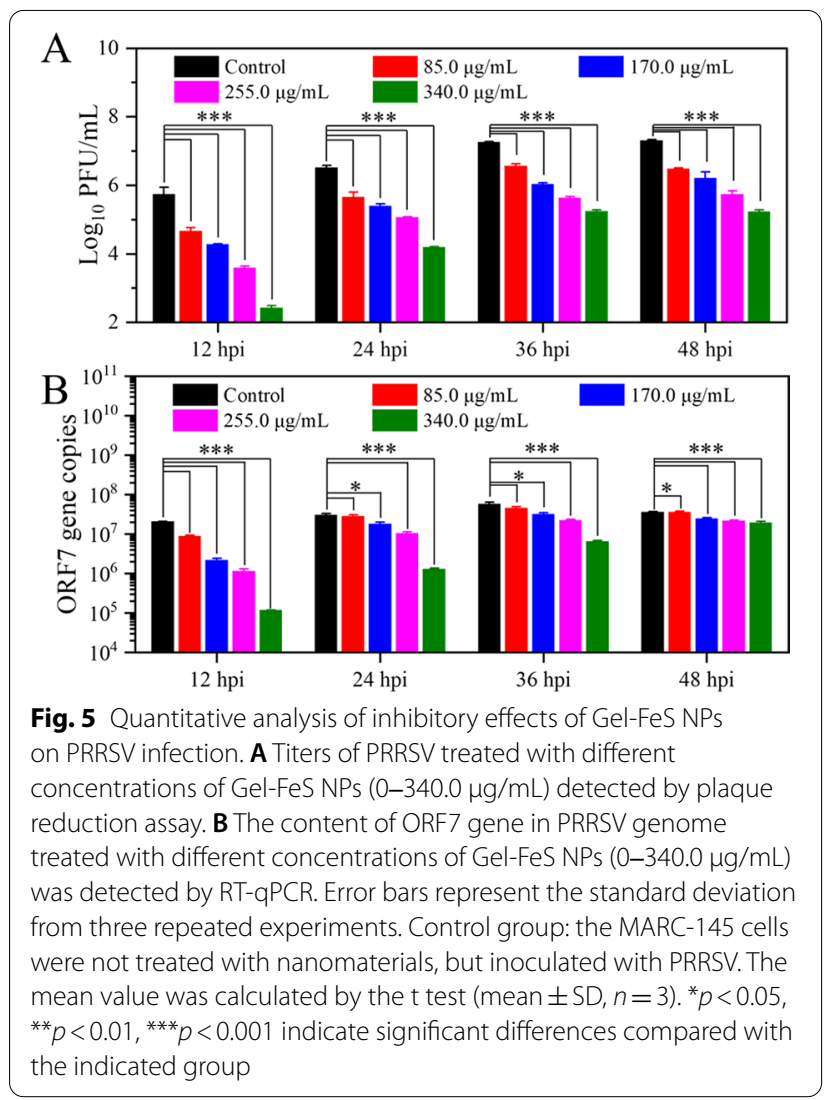

inactivate PRRSV. In Fig. 6A, inactivation assay unveiled that the PRRSV content exhibited an extremely significant $(\mathrm{p}<0.001)$ dose-dependent decrease, indicating that Gel-FeS NPs possess virucidal activity in vitro.

PRRSV infection involves a series of stages, and each stage may be a potential target of antiviral drugs. According to the reported life cycle characteristics of PRRSV and classical experimental methods [46], the effect of Gel-FeS NPs on each stage of PRRSV proliferation was explored, and the number of plaques can directly reflect their effect on the virus proliferation. In Fig. $6 \mathrm{~B}, \mathrm{C}$, the PRRSV content showed tenfold decrease in MARC145 cells treated with Gel-FeS NPs during the two stages of adsorption and invasion, implying that Gel-FeS NPs could inhibit PRRSV adsorption and invasion to MARC145 cells.

Following invasion by receptor-mediated endocytosis and disassembly, replicase polyproteins were produced under the guide of PRRSV genome positive strand RNA. This process is isolated as a PRRSV genome replication process, so the level of negative-sense RNA of PRRSV genome was quantified to assess the antiviral effect of Gel-FeS NPs on PRRSV replication by RTqPCR. In Fig. 6D, the level of PRRSV negative-sense RNA decreased slightly after treatment with $340.0 \mu \mathrm{g} / \mathrm{mL}$
Gel-FeS NPs, suggesting that Gel-FeS NPs had a moderate inhibitory effect on PRRSV replication. In Fig. 6E, F, the release experimental results indicated the Gel-FeS NPs had no influence on PRRSV release, with no significant change observed in the virus content in either intracellular or supernatant samples. In general, Gel-FeS NPs could inhibit PRRSV adsorption, invasion, and replication in MARC-145 cells, but not its release in the cells.

\section{Inhibitory effect of ferrous ion on PRRSV proliferation}

In order to further understand the inhibition mechanism of Gel-FeS NPs on PRRSV proliferation, we investigated the inhibitory effect of the individual synthetic raw materials $\left(\mathrm{FeSO}_{4}, \mathrm{Na}_{2} \mathrm{~S}\right.$, and gelatin) on PRRSV proliferation. In Additional file 1: Fig. S5A and B, the cell relative viability was seen to be about $75 \%$ at $60.0 \mu \mathrm{g} / \mathrm{mL} \mathrm{Fe}^{2+}$ concentration, in contrast to great reduction after incubation with $80.0 \mu \mathrm{g} / \mathrm{mL}$ of ferrous ions and $\mathrm{S}^{2-}$, but with little cytotoxicity at $40.0 \mu \mathrm{g} / \mathrm{mL}$ concentration. Meanwhile, gelatin exhibited good biocompatibility at high concentrations $(0-340.0 \mu \mathrm{g} / \mathrm{mL})$ (Additional file 1: Fig. S5C). Therefore, $40.0 \mu \mathrm{g} / \mathrm{mL}$ of $\mathrm{Fe}^{2+}$ and $\mathrm{S}^{2-}$ was selected to explore their antiviral activity by IFA, and the same concentration $(255.0 \mu \mathrm{g} / \mathrm{mL})$ as Gel-FeS NPs was used to explore the antiviral activity of gelatin. In Additional file 1: Fig. S5D, compared with the control cells, the cells treated by $\mathrm{FeSO}_{4}$ showed significant reduction in Alexa Fluor $^{\circledR} 594$ labeled PRRSV N protein, in contrast to no visible differences in the cells treated by $\mathrm{Na}_{2} \mathrm{~S}$ and gelatin, indicating that the $\mathrm{FeSO}_{4}$ in the synthetic raw materials of Gel-FeS NPs had antiviral activity against PRRSV. This result confirmed our hypothesis that ferrous ion has antiviral activity, indicating the $\mathrm{Fe}(\mathrm{II})$ in Gel-FeS NPs plays a dominant role in inhibiting PRRSV proliferation.

The conclusion that $\mathrm{Fe}(\mathrm{II})$ inhibits virus proliferation can be further confirmed by the test results of CMC-FeS NPs and Gelatin NPs. In Additional file 1: Fig. S6A and B, CMC-FeS NPs showed similar cytotoxicity to Gel-FeS NPs, while Gelatin NPs showed better biocompatibility. In Additional file 1: Fig. S6C, the IFA results showed that CMC-FeS NPs had a certain antiviral effect and Gelatin NPs had no obvious antiviral effect at the same concentration of Gel-FeS NPs. These results further confirmed that Fe (II) plays a key role in inhibiting PRRSV proliferation.

\section{Discussion}

Iron is an essential element for many organisms in maintaining the basic cellular physiological activities (such as oxygen transport, DNA replication, metabolic processes, etc.), and many proteins with crucial roles in cellular physiology require iron to function [37]. A series of diseases are associated with iron deficiency when 

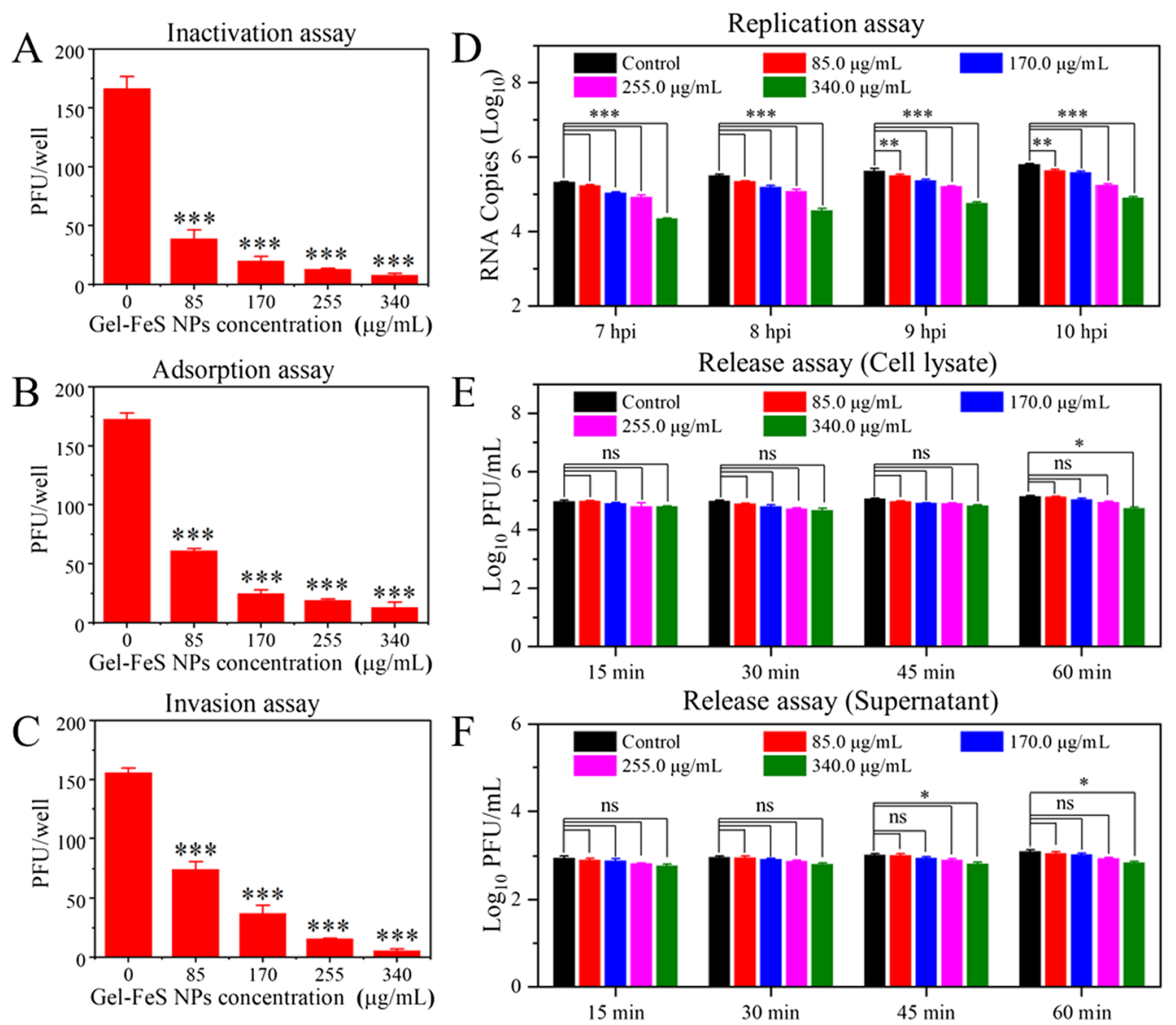

Fig. 6 Multiple-stage effect of Gel-FeS NPs on PRRSV proliferation. A Inactivation effect of Gel-FeS NPs on PRRSV. The effect of Gel-FeS NPs on the PRRSV infectivity of MARC-145 cells in the infection process of $\mathbf{B}$ adsorption, $\mathbf{C}$ invasion, $\mathbf{D}$ replication, and $\mathbf{E}$, $\mathbf{F}$ release (intracellular and supernatant samples, respectively). Error bars represent the standard deviation from three repeated experiments. Control group: the MARC-145 cells were not treated with nanomaterials, but inoculated with PRRSV. The mean value was calculated by the t test (mean $\pm S D, n=3$ ). ${ }^{*} p<0.05$, ${ }^{* *} p<0.01$, ${ }^{* * *} p<0.001$ indicate significant differences compared with the indicated group

iron-requiring enzymes become ineffective, such as many HIV-positive patients, who suffer from iron deficiency, which reduces their ability to resist viral infections, especially when the virus attacks immune cells [47]. Previous studies have shown that iron ions have antiviral activity and are essential for activating the host's antiviral immune mechanism [48]. As an example, Fe (III) can effectively inhibit the replication of HSV-1 and bovine viral diarrhea virus (BVDV) [24], and it is also speculated to interact with viral RNA [49], which may hinder the replication of the viral genome. Extracellular iron, such as FAC, can also inhibit the infection of HIV-1 by suppressing the release of HIV-1 from lysosomes and block the replication of dengue virus by activating the activity of reactive oxygen species (ROS) in the intestinal epithelium of mosquitoes [25]. However, high concentrations of iron ions may produce strong cytotoxicity, and the survival rate of cells was shown to be less than $50 \%$ when cultured with $40 \mu \mathrm{g} / \mathrm{mL}$ ferrous ions. Therefore, how to improve the biocompatibility and antiviral effect of iron ion is of great significance for its application in antiviral field.

The present study found significant improvement in biocompatibility and antiviral effects by incorporating ferrous ions into Gel-FeS NPs. The ferrous sulfide nanoparticles synthesized here has an average size $47.3 \mathrm{~nm}$, similar to the size of PRRS virions $(50-74 \mathrm{~nm})$ [44], which can inhibit virus proliferation through multiple stages. Our results indicated that Gel-FeS NPs could not only directly inactivate PRRSV in vitro, but also effectively inhibit PRRSV proliferation in the stages of adsorption and invasion, blocking the virus outside cells or from entering host cells, thus playing an important role in infection inhibition. As a highly biocompatible material, gelatin has been used in the research of drug delivery, wound adjuvant, vaccine adjuvant, and so on [49-52]. The targeting and antiviral effects of the gelatin-modified 
nanoparticles prepared here can be further improved by coating antiviral drugs or modified functional molecules on their surface in the future studies.

ROS, the by-products of cellular metabolism, are potential antiviral targets [53], and several viral infections were shown to cause an increase in intracellular ROS, mainly due to viral-induced imbalances in the antioxidant defense mechanisms of the cell, thereby activating certain host cellular pathways and promoting viral replication [54, 55]. Nano-sized iron (II) complex has been reported to possess excellent radical-scavenging activities and high antiviral activity against tobacco mosaic viruses (TMV) [56]. This suggests the possibility that Gel-FeS NPs might also inhibit viral infection by mediating the level of ROS induced by PRRSV infection, so we tested this possibility by the fluorescent probe DCFH-DA. The DCFH-DA results showed no significant difference between the control and Gel-FeS NPs-treated cells in the intensity of the green fluorescence signals (Additional file 1: Fig. S7), indicating that Gel-FeS NPs do not inhibit PRRSV proliferation by decreasing its ROS production in the host cell.

In this work, we found that the integration of ferrous ions into Gel-FeS NPs could significantly improve the biocompatibility and antiviral effects of ferrous ions-based NPs. They were demonstrated high antiviral activity against PRRSV proliferation in the stages of adsorption, invasion, and replication. Moreover, the $\mathrm{Fe}^{2+}$ released from degraded Gel-FeS NPs still displayed an antiviral effect, indicating the advantage of Gel-FeS NPs as an antiviral nanomaterial compared to other nanomaterials. This work highlighted the antiviral effect of GelFeS NPs and provided a new strategy for ferrous-based nanoparticles against PRRSV. However, despite their good antiviral effect in vitro, the in vivo and clinical applications of Gel-FeS NPs need more consideration, such as adjusting the synthesis and storage method according to the type of antiviral drugs (oral or injection).

\section{Conclusion}

In this paper, we reported the virucidal and antiviral activity of Gel-FeS NPs for the first time. The Gel-FeS NPs with good dispersibility and biocompatibility were large-scale synthesized rapidly in a one-pot method, and they exhibited effective inhibition on PRRSV adsorption, invasion, and replication in MARC-145 cells. Moreover, the ferrous ions from degraded ferrous sulfide still displayed an antiviral effect, demonstrating the advantage of Gel-FeS NPs as an antiviral nanomaterial relative to other nanomaterials. This work highlighted the antiviral effect of Gel-FeS NPs and provided a new strategy for ferrousbased nanoparticles against PRRSV.

\section{Methods}

\section{Preparation of FeS NPs}

Stable Gel-FeS NPs were synthesized through a coprecipitation method based on the reaction of $\mathrm{FeSO}_{4}$ with $\mathrm{Na}_{2} \mathrm{~S}$ in the presence of gelatin. Briefly, under continuous magnetic stirring and high-purity nitrogen flow conditions, $20.0 \mathrm{~mL} \mathrm{FeSO}_{4}(0.020 \mathrm{~mol} / \mathrm{L})$ and $50.0 \mathrm{~mL}$ gelatin $(1.0 \mathrm{~g} / \mathrm{L})$ solutions were mixed in a three-necked flasks, followed by stirring the mixture for $30 \mathrm{~min}$ to yield $\mathrm{Fe}^{2+}$-gelatin complexes, and adding $20.0 \mathrm{~mL} \mathrm{Na} \mathrm{S}_{2} \mathrm{~S}$ $(0.020 \mathrm{~mol} / \mathrm{L})$ solution dropwise at an Fe-to-S molar ratio of $1: 1$ to produce FeS nanoparticles [31]. After centrifugation of the obtained solution at 10,000 rpm for $10 \mathrm{~min}$, the supernatant was collected and directly vacuum freeze-dried to solid state for storage.

For synthesizing CMC-FeS NPs, CMC was used instead of gelatin, and the synthesis method is similar as described above.

\section{Cytotoxicity assay}

MARC-145 cells were seeded in 96-well plates and cultured to approximately $80-90 \%$ confluence, followed by incubation with Gel-FeS NPs at different concentrations $(0,14.0,28.0,54.0,108.0,215.0$, and $430.0 \mu \mathrm{g} / \mathrm{mL})$. Meanwhile, cells treated with the DMEM (2\% FBS) were used as the control. After incubation separately for 12, 24, 36 and $48 \mathrm{~h}$, the standard MTT assay was used to evaluate the cell viability [57].

\section{Cell internalization experiment of Gel-FeS NPs}

MARC-145 cells were seeded in 24-well plates and cultured to approximately $100 \%$ confluence, followed by incubation with Gel-FeS NPs at different concentrations $(0,170.0$ and $340.0 \mu \mathrm{g} / \mathrm{mL})$. Meanwhile, cells treated with the DMEM (2\% FBS) were used as the control. After incubation separately for $0.5,1.5,3$ and $5 \mathrm{~h}$, the supernatant was removed, followed by 3 washes of the cells with PBS, and digesting the cells with $0.25 \%$ trypsin solution (WISENT, 325-043-EL) to a single cell. All trypsin digested cell samples were collected and nitrated with nitric acid (AR, Sinopharm Chemical Reagent) overnight. Iron standard (Aladdin, 7439-89-6) was purchased and diluted to the specified concentration $(20-100 \mathrm{ppb})$, the samples were diluted with $1 \%$ dilute nitric acid for ICPMS detection. The experiment was repeated three times in order to calculate the relative standard deviation.

\section{Intracellular ferrous ion release assay}

MARC-145 cells were seeded in 24-well plates and cultured to approximately $100 \%$ confluence, followed by incubation with Gel-FeS NPs at different concentrations $(0,170.0$ and $340.0 \mu \mathrm{g} / \mathrm{mL})$. Meanwhile, cells treated with 
the DMEM (2\% FBS) were used as the control. After incubation separately for $2,6,10$ and $20 \mathrm{~h}$, the supernatant was removed, followed by washing the cells 3 times with PBS, and digesting the cells with $0.25 \%$ trypsin solution (without EDTA and phenol red) (Solarbio, T1350) to a single cell. The content of intracellular ferrous ions was detected as instructed by the manufacturer (Elabscience, E-BC-K304-S).

\section{Antiviral assay}

MARC-145 cells were incubated with Gel-FeS NPs at different concentrations $(0,85.0,170.0,255.0$, and $340.0 \mu \mathrm{g} /$ $\mathrm{mL}$ ) for $2 \mathrm{~h}$ at $37^{\circ} \mathrm{C}$. Meanwhile, PRRSV was pretreated with Gel-FeS NPs at $4{ }^{\circ} \mathrm{C}$ for $1 \mathrm{~h}$. Then, the cells were incubated with the pretreated PRRSV at the multiplicity of infection (MOI) of 1.0 for $1 \mathrm{~h}$. Next, the inoculums were discarded, followed by two washes with DMEM, and incubation of the cells with Gel-FeS NPs at the corresponding concentration and $37^{\circ} \mathrm{C}$ for $12,24,36$ and $48 \mathrm{~h}$, respectively. Finally, the cell samples were collected for IFA and plaque reduction assay [46].

\section{Indirect immunofluorescence assay}

MARC-145 cells were cultured in 24-well plates and collected at indicated time points, followed by three washes with PBS, treating the cells with $4 \%$ paraformaldehyde for $15 \mathrm{~min}$, and permeabilizing the cells with precooled methanol at $-20{ }^{\circ} \mathrm{C}$ for $15 \mathrm{~min}$. Next, the cells were blocked by $5 \%(\mathrm{w} / \mathrm{v})$ BSA for $45 \mathrm{~min}$ and then detected with a mouse monoclonal antibody (primary antibodies) against the PRRSV N protein and Alexa Fluor ${ }^{\circledR} 594$-conjugated Donkey anti mouse lgG (secondary antibodies), Cell nucleus was stained by DAPI [58]. The fluorescence images were acquired with Laser confocal microscope LSM880 (ZEISS, Germany).

\section{Plaque reduction assay}

Briefly, MARC-145 cells were seeded in 6-well plates and cultured until $\sim 100$ confluence, followed by adding the indicated samples to the plates by tenfold gradient dilution with DMEM (2\% FBS) and incubation for $1.5 \mathrm{~h}$. After discarding the supernatant, the cells were washed three times with DMEM to remove non-absorbed PRRS virions, followed by adding to each well $2 \mathrm{~mL}$ overlay medium $(2 \times$ DMEM:low melting point agarose $1.8 \% \quad(\mathrm{w} / \mathrm{w}):$ FBS: penicillin - streptomycin $=48: 48: 3: 1)$, and cooling for $15 \mathrm{~min}$ at $4{ }^{\circ} \mathrm{C}$ to coagulate the overlay medium. After incubation at $37{ }^{\circ} \mathrm{C}$ for $2 \sim 3$ days, the cells were stained with $1.0 \mathrm{~mL}$ neutral red solution $(0.50 \mathrm{mg} /$ $\mathrm{mL}$ ) for $1 \mathrm{~h}$ at $37^{\circ} \mathrm{C}$, followed by removing the supernatant and storing the plates at $4{ }^{\circ} \mathrm{C}$ overnight [59]. Finally, the number of plaques was counted and virus titers were calculated. All the virus titers were presented as plaque forming units $(\mathrm{PFU} / \mathrm{mL})$.

\section{Inactivation assay}

The plaque assay was performed to investigate whether Gel-FeS NPs could directly inactivate PRRSV. Briefly, different contents of PRRSV $(\mathrm{MOI}=1.0,0.1,0.01,0.001$, and 0.0001 ) were used for pre-experiments to find a suitable PRRSV concentration for plaque assay of the effect of Gel-FeS NPs on the inactivation of PRRSV [60]. PRRSV $(\mathrm{MOI}=0.001)$ was incubated with Gel-FeS NPs at different concentrations $(0,85.0,170.0,255.0$, and $340.0 \mu \mathrm{g} /$ $\mathrm{mL}$ ) for $1 \mathrm{~h}$ at $37^{\circ} \mathrm{C}$. The 6 -well plates were pre-chilled separately at $4{ }^{\circ} \mathrm{C}$ for $30 \mathrm{~min}$ when cells reached $100 \%$ confluence, followed by adding the pretreated PRRSV to the 6-well plates. After incubation at $4{ }^{\circ} \mathrm{C}$ for $2 \mathrm{~h}$, the cells were covered with overlay medium for the corresponding plaque assay.

\section{Adsorption assay}

The MARC-145 cells cultured in 6-well plates were prechilled at $4{ }^{\circ} \mathrm{C}$ for $30 \mathrm{~min}$, followed by incubation with the PRRSV $(\mathrm{MOI}=0.001)$ and Gel-FeS NPs of different concentrations $(0,85.0,170.0,255.0$, and $340.0 \mu \mathrm{g} / \mathrm{mL})$ at $4{ }^{\circ} \mathrm{C}$ for $2 \mathrm{~h}$ [61]. Finally, the cells were washed three times with pre-cooled DMEM and covered with overlay medium for the corresponding plaque assay.

\section{Invasion assay}

The MARC-145 cells were cultured in 6-well plates and pre-chilled at $4{ }^{\circ} \mathrm{C}$ for $30 \mathrm{~min}$, followed by infection with PRRSV $(\mathrm{MOI}=0.001)$ at $4{ }^{\circ} \mathrm{C}$ for $2 \mathrm{~h}$, and three washes with pre-cooled DMEM. Next, the virus-containing medium was replaced by fresh medium containing GelFeS NPs of different concentrations $(0,85.0,170.0,255.0$, and $340.0 \mu \mathrm{g} / \mathrm{mL}$ ). After incubation at $37^{\circ} \mathrm{C}$ for $3 \mathrm{~h}$, the supernatant was discarded, and the cells were covered with overlay medium for the corresponding plaque assay [62].

\section{Replication assay}

The MARC-145 cells in 24-well plates were infected with PRRSV (MOI $=1.0$ ) at $37{ }^{\circ} \mathrm{C}$ for $1 \mathrm{~h}$, followed by replacing the supernatant with DMEM (2\% FBS) and culturing the cells for additional $6 \mathrm{~h}$. After removing the supernatant, 24-well plates were supplemented with DMEM containing Gel-FeS NPs of different concentrations $(0,85.0,170.0,255.0$, and $340.0 \mu \mathrm{g} / \mathrm{mL})$. After incubation for another 7, 8, 9 and $10 \mathrm{~h}$, the total RNA of the infected cells was extracted using the TRIzol reagent as instructed by the manufacturer. TAKARA Reverse Transcription Kit was used to reverse transcribe RNA to cDNA according to the manufacturer's 
instructions with the primer (5'UF: GACGTATAGGTG TTGGCTC). PCR assay was performed using the primers (F: GCATTTGTATTGTCAGGAGC, R: AGCAGT GCAACTCCGGAAG) [47]. The abundance of PRRSV negative-sense RNA was quantified by RT-qPCR assay.

\section{Release assay}

The MARC-145 cells were infected with PRRSV $(\mathrm{MOI}=1.0)$ at $37^{\circ} \mathrm{C}$ for $1 \mathrm{~h}$, followed by discarding the supernatant and culturing the cells in DMEM (2\% FBS) at $37^{\circ} \mathrm{C}$ for another $18 \mathrm{~h}$. After three washes with DMEM, 24-well plates were added with fresh DMEM containing different concentrations of Gel-FeS NPs $(0$, 85.0, $170.0,255.0$, and $340.0 \mu \mathrm{g} / \mathrm{mL}$ ). After incubation for 15, 30, 45 and $60 \mathrm{~min}$, the PRRSV supernatant samples were collected, followed by adding fresh DMEM and collecting the cell lysate by freezing and thawing three times [63]. Finally, a plaque assay was performed to determine the virus content of the corresponding samples.

\footnotetext{
Abbreviations

PRRSV: Porcine reproductive and respiratory syndrome virus; FTIR: Fourier transmission infrared spectroscopy; TEM: Transmission electron microscope; XRD: X Ray diffraction; XPS: X-ray Photoelectron Spectroscopy; MTT: 3-(4,5-Dimethylthiazol-2-yl)-2,5-diphenyltetrazolium bromide; IFA: Indirect immunofluorescence assay; RT-qPCR: Real-time quantitative reverse transcription polymerase chain reaction.
}

\section{Supplementary Information}

The online version contains supplementary material available at https://doi. org/10.1186/s12951-022-01281-4.

Additional file 1. Chemicals and Reagents, Viruses and Cell Culture, Preparation of gelatin nanoparticles, Characterization of Gel-FeS NPs, Control experiment for the antiviral effect of raw materials and other nanoparticles, Measurement of the production of reactive oxygen species. Figure S1. The morphological picture and UV-Vis spectra of Gel-FeS NPs. Figure S2. Pictures of Gel-FeS NPs dispersed in different solvents. Figure S3. TEM images of CMC-FeS NPS and Gelatin NPs. Figure S4. Dynamic light scattering distribution images of CMC-FeS NPs and Gelatin NPs. Figure S5. Cytotoxicity and antiviral activity assay of of different concentrations of Fe2+, S2- and gelatin. Figure S6. Cytotoxicity and antiviral activity of FeS NPs and Gelatin NPs. Figure S7. Effect of Gel-FeS NPs on PRRSV-induced ROS production.

\section{Acknowledgements}

Not applicable.

\section{Authors' contributions}

LJG, XSB provided the conception and design of the study. TT and DSF carried out experiments, Tong $T$ discussed the results. ZXT assisted the experiments, Professor Fang LR provided the experimental platform, TT, LJG, Xiao SB cowrote the paper. All authors read and approved the final manuscript.

\section{Funding}

This study was supported by the National Natural Science Foundation of China $(32130103,31772785,22074048)$
Availability of data and materials

Not applicable.

\section{Declarations}

Ethics approval and consent to participate

Not applicable.

\section{Consent for publication}

Not applicable.

\section{Competing interests}

The authors declare that they have no competing interests.

Received: 21 October 2021 Accepted: 21 January 2022

Published online: 05 February 2022

\section{References}

1. Chae C. Commercial PRRS Modified-Live Virus Vaccines. Vaccines. 2021;9(2):185.

2. Lunney JK, Fang Y, Ladinig A, Chen NH, Li YH, Rowland B, Renukaradhya GJ. Porcine reproductive and respiratory syndrome virus (PRRSV): Pathogenesis and interaction with the immune system. Annu Rev Anim Biosci. 2016:4:129-54.

3. Ma J, Ma LL, Yang MT, Wu W, Feng W, Chen Z. The function of the PRRSVhost interactions and their effects on viral replication and propagation in antiviral strategies. Vaccines. 2021;9(4):364.

4. Reina $G$, Peng S, Jacquemin L, Andrade AF, Bianco A. Hard nanomaterials in time of viral pandemics. ACS Nano. 2020;14(8):9364-88.

5. Lee J, Sands I, Zhang WX, Zhou LB, Chen YP. DNA-inspired nanomaterials for enhanced endosomal escape. Proc Natl Acad Sci U S A. 2021;118(19):2104511118.

6. Mirtaleb MS, Mirtaleb AH, Nosrati H, Heshmatnia J, Falak R, Emameh RZ. Potential therapeutic agents to COVID-19: An update review on antiviral therapy, immunotherapy, and cell therapy. Biomed Pharmacother. 2021;138:111518

7. Yoon BK, Jeon WY, Sut TN, Cho NJ, Jackman JA. Stopping membraneenveloped viruses with nanotechnology strategies: Toward antiviral drug development and pandemic preparedness. ACS Nano. 2021;15(1):125-48.

8. Chen L, Liang JG. An overview of functional nanoparticles as novel emerging antiviral therapeutic agents. Mater Sci Eng C Mater Biol Appl. 2020;112:110924.

9. Kwon PS, Ren S, Kwon SJ, Kizer ME, Kuo L, Xie M, Zhu D, Zhou F, Zhang FM, Kim D, Fraser K, Kramer LD, Seeman NC, Dordick JS, Linhardt RJ, Chao J, Wang X. Designer DNA architecture offers precise and multivalent spatial pattern-recognition for viral sensing and inhibition. Nat Chem. 2020;12(1):26-35.

10. Park SJ, Kim J, Kang S, Cha HJ, Shin H, Park J, Jang YS, Woo JS, Won C, Min $\mathrm{DH}$. Discovery of direct-acting antiviral agents with a graphene-based fluorescent nanosensor. Sci Adv. 2020;6(22):e8201.

11. Anand A, Unnikrishnan B, Wei SC, Chou CP, Zhang LZ, Huang CC. Graphene oxide and carbon dots as broad-spectrum antimicrobial agents - a minireview. Nanoscale Horiz. 2019;4(1):117-37.

12. Muñoz A, Sigwalt D, Illescas BM, Luczkowiak J, Rodriguez-Perez L, Nierengarten I, Holler M, Remy JS, Buffet K, Vincent SP, Rojo J, Delgado R, Nierengarten JF, Martin N. Synthesis of giant globular multivalent glycofullerenes as potent inhibitors in a model of Ebola virus infection. Nat Chem. 2016;8(1):50-7.

13. Ramos-Soriano J, Reina JJ, Illescas BM, de la Cruz N, Rodríguez-Pérez L, Lasala F, Rojo J, Delgado R, Martin N. Synthesis of highly efficient multivalent disaccharide/[60]fullerene nanoballs for emergent viruses. J Am Chem Soc. 2019;141(38):15403-12.

14. Rodríguez-Pérez L, Ramos-Soriano J, Pérez-Sánchez A, Illescas BM, Munoz A, Luczkowiak J, Lasala F, Rojo J, Delgado R, Martin N. Nanocarbon-based glycoconjugates as multivalent inhibitors of Ebola virus infection. J Am Chem Soc. 2018;140(31):9891-8.

15. Kwon SJ, Na DH, Kwak JH, Douaisi M, Zhang F, Park EJ, Park JH, Youn H, Song CS, Kane RS, Dordick JS, Lee KB, Linhardt RJ. Nanostructured glycan 
architecture is important in the inhibition of influenza A virus infection. Nat Nanotechnol. 2017;12(1):48-54.

16. Wang CG, Guan YK, Lv MZ, Zhang R, Guo ZY, Wei XM, Du XX, Li T, Wan $Y$, Su XD, Huang XJ, Jiang ZF. Manganese increases the sensitivity of the CGAS-STING pathway for double-stranded DNA and is required for the host defense against DNA viruses. Immunity. 2018;48(4):675-87.

17. Zheng J, Fan R, Wu HQ, Yao HH, Yan YJ, Liu JM, Ran L, Sum ZF, Yi LZ, Dang L, Gan PP, Zheng P, Yang TL, Zhang Y, Tang T. Directed self-assembly of herbal small molecules into sustained release hydrogels for treating neural inflammation. Nat Commun. 2019;10:1604.

18. Dey P, Bergmann T, Cuellar-Camacho JL, Ehrmann S, Chowdhury MS, Zhang MZ, Haag R, Azad W. Multivalent flexible nanogels exhibit broad-spectrum antiviral activity by blocking virus entry. ACS Nano. 2018;12(7):6429-42

19. Schmitz A, Weber A, Bayin M, Breuers S, Fieberg V, Famulok M, Mayer G. A SARS-CoV-2 spike binding DNA aptamer that inhibits pseudovirus infection by an RBD-independent mechanism. Angew Chem Int Ed. 2021;60(18):10279-85.

20. Jones ST, Cagno V, Janecek M, Ortiz D, Gasilova N, Piret J, Gasbarri M, Constant DA, Han YX, Vukovi L, Kral P, Kaiser L, Huang S, Constant S, Kirkegaard K, Boivin G, Stellacci F, Tapparel C. Modified cyclodextrins as broad-spectrum antivirals. Sci Adv. 2020;6(5):e9318.

21. Fraga CG, Oteiza PI. Iron toxicity and antioxidant nutrients. Toxicology. 2002;180(1):23-32.

22. Abdel-Rahman LH, Abu-Dief AM, Newair EF, Hamdan SK. Some new nano-sized $\mathrm{Cr}(\mathrm{III}), \mathrm{Fe}(\mathrm{II}), \mathrm{Co}(\mathrm{II})$, and Ni(II) complexes incorporating 2-((E)(pyridine-2-ylimino)methyl)napthalen-1-ol ligand: structural characterization, electrochemical, antioxidant, antimicrobial, antiviral assessment and DNA interaction. J Photochem Photobiol B. 2016;160:18-31.

23. Sagripanti JL, Routson LB, Lytle CD. Virus inactivation by copper or iron ions alone and in the presence of peroxide. Appl Environ Microbiol. 1993;59(12):4374-6

24. Terpilowska S, Siwicki AK. Chromium(III) and iron(III) inhibits replication of DNA and RNA viruses. Biometals. 2017;30(4):565-74.

25. Zhu YB, Tong LQ, Nie KX, Wiwatanaratanabutr I, Sun P, Li QQ, Yu X, Wu P, Wu TS, Yu C, Liu QY, Bian ZQ, Wang PH, Cheng G. Host serum iron modulates dengue virus acquisition by mosquitoes. Nat Microbiol. 2019:4(12):2405-15.

26. Wang HB, Li Z, Niu JL, Xu YF, Ma L, Lu AL, Wang X, Qian ZK, Huang Z, Jin $X$, Leng QB, Wang JH, Zhong J, Sun B, Meng GX. Antiviral effects of ferric ammonium citrate. Cell Discov. 2018;4:14.

27. Urso K, Martínez-Bujanda JL, Prado JMD. Iron protein succinylate in the management of iron deficiency anemia: A comparative study with ferrous sulphate at low and high therapeutic doses. Nutrients. 2021;13(3):968

28. Okonko DO, Grzeslo A, Witkowski T, Mandal AKJ, Slater RM, Roughton M, Foldes G, Thum T, Majda J, Banasiak W, Missouris CG, Poole-Wilson PA, Anker SD, Ponikowski P. Effect of intravenous iron sucrose on exercise tolerance in anemic and nonanemic patients with symptomatic chronic heart failure and iron deficiency FERRIC-HF: A randomized, controlled, observer-blinded trial. J Am Coll Cardiol. 2008:51(2):103-12.

29. Liu Y, Li Y, Kang H, Jin T, Jiao LF. Design, synthesis, and energy-related applications of metal sulfides. Mater Horiz. 2016;3(5):402-21.

30. Chen YN, Liang WY, Li YP, Wu YX, Chen YR, Xiao W, Zhao L, Zhang JC, Li H. Modification, application and reaction mechanisms of nano-sized iron sulfide particles for pollutant removal from soil and water: A review. Chem Eng J. 2019;362:144-59.

31. Xiong Z, He F, Zhao DY, Barnett MO. Immobilization of mercury in sediment using stabilized iron sulfide nanoparticles. Water Res. 2009:43(20):5171-9.

32. Dong $Z X$, Meng $X Y$, Yang W, Zhang JF, Sun $P$, Zhang HW, Fang $X$, Wang DA, Fan CJ. Progress of gelatin-based microspheres (GMSs) as delivery vehicles of drug and cell. Mater Sci Eng C Mater Biol Appl. 2021:122:111949.

33. Khan MR, Sadiq MB. Importance of gelatin, nanoparticles and their interactions in the formulation of biodegradable composite films: a review. Polym Bull. 2020;78(7):4047-73.

34. Sun Y, Liu YL, Lou ZM, Yang KL, Lv D, Zhou JS, Baig SA, Xu XH. Enhanced performance for $\mathrm{Hg}$ (II) removal using biomaterial (CMC/gelatin/starch) stabilized FeS nanoparticles: Stabilization effects and removal mechanism. Chem Eng J. 2018;344:616-24.
35. Shao DD, Ren XM, Wen J, Hu S, Xiong J, Jiang T, Wang XL, Wang XK. Immobilization of uranium by biomaterial stabilized FeS nanoparticles: Effects of stabilizer and enrichment mechanism. J Hazard Mater. 2016;302:1-9.

36. Zhou LH, Wei XC, Ma ZJ, Mei B. Anti-friction performance of FeS nanoparticle synthesized by biological method. Appl Surf Sci. 2017;407:21-8.

37. Guo YX, Yao ZY, Timmer BJJ, Sheng X, Fan LZ, Li YY, Zhang FG, Sun LC. Boosting nitrogen reduction reaction by bio-inspired FeMoS containing hybrid electrocatalyst over a wide pH range. Nano Energy. 2019;62:282-8.

38. Malek TJ, Chaki SH, Deshpande MP. Structural, morphological, optical, thermal and magnetic study of mackinawite FeS nanoparticles synthesized by wet chemical reduction technique. Phys B. 2018;546:59-66.

39. Johnson CR, Griggs TF, Gnanandarajah J, Murtaugh MP. Novel structural protein in porcine reproductive and respiratory syndrome virus encoded by an alternative ORF5 present in all arteriviruses. J Gen Virol. 2011:92:1107-16.

40. Yim-Im W, Huang HY, Park J, Wang C, Calzada G, Gauger P, Harmon K, Main R, Zhang JQ. Comparison of ZMAC and MARC-145 Cell lines for improving porcine reproductive and respiratory syndrome virus isolation from clinical samples. J Clin Microbiol. 2021;59(3):e01757.

41. Tong T, Hu HW, Zhou JW, Deng S, Zhang XT, Tang WT, Fang LR, Xiao SB, Liang JG. Glycyrrhizic-acid-based carbon dots with high antiviral activity by multisite inhibition mechanisms. Small. 2020;16(13):1906206.

42. Dang Z, Guan Y, Wu Z, Tao XY, Xiong Y, Bai HB, Shao CS, Liu G, Huang $\mathrm{Q}$, Tian $L$ J, Tian YC. Regulating the synthesis rate and yield of bioassembled FeS nanoparticles for efficient cancer therapy. Nanoscale. 2021;13(45):18977-86.

43. Song Y, Duan L, Du K, Song C, Zhao S, Yuan X, Wang S, Yan Z. Nano zerovalent iron harms methanogenic archaea by interfering with energy conservation and methanogenesis. Environ Sci: Nano. 2021;8(12):3643-54.

44. Dokland T. The structural biology of PRRSV. Virus Res. 2010;154:86-97.

45. Li Y, Tas A, Sun Z, Snijder EJ, Fang Y. Proteolytic processing of the porcine reproductive and respiratory syndrome virus replicase. Virus Res. 2015;202:48-59.

46. Zhou YR, Tong T, Jiang XH, Fang L, Wu Y, Liang J, Xiao SB. GSH-ZnS nanoparticles exhibit high-efficiency and broad-spectrum antiviral activities via multistep inhibition mechanisms. ACS Appl Bio Mater. 2020;3(8):4809-19.

47. Duan EZ, Wang D, Fang LR, Ma J, Luo JY, Chen HC, Li K, Xiao SB. Suppression of porcine reproductive and respiratory syndrome virus proliferation by glycyrrhizin. Antiviral Res. 2015;120:122-5.

48. DuTF, Nan YC, Xiao SQ, Zhao Q, Zhou EM. Antiviral strategies against PRRSV infection. Trends Microbiol. 2017;25(12):968-79.

49. Chhabra R, Saha A, Chamani A, Schneider N, Shah R, Nanjundan M. Iron pathways and iron chelation approaches in viral, microbial, and fungal infections. Pharmaceuticals. 2020;13(10):275.

50. Drakesmith H, Prentice A. Viral infection and iron metabolism. Nat Rev Microbiol. 2008;6(7):541-52.

51. Zhang S, Cao YN, Yang Q. Transferrin receptor 1 levels at the cell surface influence the susceptibility of newborn piglets to PEDV infection. PLOS Pathog. 2020;16(7):1008682.

52. Khan N, Chen X, Geiger JD. Role of divalent cations in HIV-1 replication and pathogenicity. Viruses. 2020;12(4):471.

53. Kim HO, Yeom MJ, Kim J, Kukreja A, Na W, Choi J, Kang A, Yun D, Lim JW, Song D, Haam SJ. Reactive oxygen species-regulating polymersome as an antiviral agent against influenza virus. Small. 2017;13(32):1700818.

54. Kanga Jl, Park KM. Advances in gelatin-based hydrogels for wound management. J Mater Chem B. 2021;9(6):1503-20.

55. Hussain A, Hasan A, Babadaei MMN, Bloukh SH, Edis Z, Rasti B, Sharifi M, Falahati M. Application of gelatin nanoconjugates as potential internal stimuli-responsive platforms for cancer drug delivery. J Mol Liq. 2020;318:114053.

56. Rigueto CVT, Nazari MT, Massuda LÁ, Ostwald BEP, Piccin JS, Dettmer A. Production and environmental applications of gelatin-based composite adsorbents for contaminants removal: a review. Environ Chem Lett. 2021;19:2465-86

57. Li CM, Zheng LL, Yang XX, Wan XY, Wu WB, Zhen SJ, Li YF, Luo LF, Huang CZ. DNA-AuNP networks on cell membranes as a protective barrier to inhibit viral attachment, entry and budding. Biomaterials. 2016;77:216-26. 
58. Du T, Zhang JY, Li CQ, Song T, Li P, Liu JF, Du XJ, Wang S. Gold/Silver hybrid nanoparticles with enduring inhibition of coronavirus multiplication through multisite mechanisms. Bioconjug Chem. 2020;31(11):2553-63.

59. Yang XX, Li CM, Huang CZ. Curcumin modified silver nanoparticles for highly efficient inhibition of respiratory syncytial virus infection. Nanoscale. 2016;8(5):3040-8.

60. Du T, Liang JG, Dong N, Lu J, Fu YY, Fang LR, Xiao SB, Han HY. Glutathionecapped $\mathrm{Ag}_{2} \mathrm{~S}$ nanoclusters inhibit coronavirus proliferation through blockage of viral RNA synthesis and budding. ACS Appl Mater Interfaces. 2018;10(5):4369-78.

61. Zhu Z, Guo Y, Yu P, Wang X, Zhang X, Dong W, Liu X, Guo C. Chlorine dioxide inhibits the replication of porcine reproductive and respiratory syndrome virus by blocking viral attachment. Infect Genet Evol. 2019;67:78-87.

62. Feng J, Bai X, Cui T, Zhou H, Chen Y, Xie J, Shi Q, Wang H, Zhang G. In vitro antiviral activity of germacrone against porcine reproductive and respiratory syndrome virus. Curr Microbiol. 2016;73(3):317-23.

63. Wang R, Yu Y, Kong W, Li C, Kang Y, Wang G, Wang W, He J, Zhao M.

Molecular cloning of porcine 2,'5'-oligoadenylate synthetase-like protein and its role in porcine reproductive and respiratory syndrome virus infection. Microb Pathog. 2018;125:281-9.

\section{Publisher's Note}

Springer Nature remains neutral with regard to jurisdictional claims in published maps and institutional affiliations.

- fast, convenient online submission

- thorough peer review by experienced researchers in your field

- rapid publication on acceptance

- support for research data, including large and complex data types

- gold Open Access which fosters wider collaboration and increased citations

- maximum visibility for your research: over 100M website views per year

At BMC, research is always in progress.

Learn more biomedcentral.com/submissions 